\title{
Towards a Pattern Language for Hybrid Education
}

\author{
CHRISTIAN KÖPPE, HAN University of Applied Sciences, Arnhem/Nijmegen, the Netherlands \\ RIKKE TOFT NØRGÅRD, Aarhus University, Denmark \\ ALEX YOUNG PEDERSEN, Aarhus University, Denmark
}

\begin{abstract}
In this paper we offer an initial framework for a pattern language of hybrid education. With the term hybrid education, we imply the use of educational design patterns that actively strive to cut across, circumventing or upheave traditional dichotomies within education such as physical-digital, academic-nonacademic, online-offline, formal-informal, learning-teaching and individual-collective. In doing so, hybrid education invites uncertainty, open-endedness, risk-taking, experimentation, critical creativity, disruption, dialogue and democracy (back) into the heart of education. Accordingly we see, within hybrid education, the promise to push against and circumvent current trends of marketization, managerialism and standardization in higher education today. Here, a pattern language for hybrid education presents an alternative way of designing for future higher education in ways that are not focused on teaching to the test, playing it safe, rankings or gaming the system approaches. Rather, hybrid education focuses on open-endedness, risk-taking, relational entanglements, experimentation, exploration and empathy. In this way, designing for hybrid education is in this paper achieved, partly by taking a decidedly value-based and vision-driven approach to learning design patterns based on philosophy in higher education and critical pedagogy, partly by working together in hybrid ways and across disciplines and domains in order to open up both the field of teaching and learning in higher education as well as the field of learning design and design patterns. The result is the almost 80 design patterns for hybrid education. The paper presents the pattern categories for hybrid education, the different design patterns contained in these. Furthermore, the pattern mining ground and workshop process, the outcome of the value workshop and the vision workshop as well as three example scenarios is described in order to show both the underlying value and vision foundation for the pattern language as well as how it plays out in concrete scenarios.

Categories and Subject Descriptors: K.3.2 [Computers and Education]: Computer and Information Science Education —Computer science education General Terms: Design, Education
\end{abstract}

Additional Key Words and Phrases: Educational Patterns, Hybrid Pedagogy

ACM Reference Format:

Köppe, C., Nørgård, R.T., Pedersen, A.Y. 2017. Towards a Pattern Language for Hybrid Education - Proceedings of the VikingPLoP 2017 conference (April 2017), 17 pages.

\section{INTRODUCTION}

"Hybridity is about the moment of play, in which the two sides of the binary begin to dance around (and through) one another before landing in some new configuration. [Hybrid Education] is not just about what will become of us in the wake of technological and cultural transformation, but also (and perhaps more predominantly) about the process of becoming itself." [Stommel 2012]

Within higher education research there is a general acknowledgment of the growing trends of marketization, managerialism and standardization of education that emphasize performance outcomes, cost effectiveness, teacher and student efficiency, and managerial competence as critically discussed by e.g. [Land 2004; Budd 2017; Shumar 1997; Barnett 2004; 2010; 2013; Filippakou and Williams 2015]. These shifts run the risk of promoting phenomena such as teaching to

Corresponding author: christian.koppe@han.nl

Permission to make digital or hard copies of all or part of this work for personal or classroom use is granted without fee provided that copies are not made or distributed for profit or commercial advantage and that copies bear this notice and the full citation on the first page. Copyrights for components of this work owned by others than the author(s) must be honored. Abstracting with credit is permitted. To copy otherwise, or republish, to post on servers or to redistribute to lists, requires prior specific permission and/or a fee. Request permissions from Permissions@acm.org. VikingPLoP'17, March 30 - April 2, Grube, Schleswig-Holstein, Germany. Copyright is held by the owner/author(s). Publication rights licensed to ACM. ACM ISBN 978-1-4503-6342-6/17/03 \$15.00 https://doi.org/10.1145/3158491.3158504 
the test, gaming the system, defensive teaching, and playing it safe in what Nixon calls 'the corporate university' and 'the knowledge factory' [Nixon 2008]. Furthermore, the above research establishes links between these phenomena and the growing focus on metrics, learning analytics, measure of performance, teacher excellence frameworks, clear learning goals, criteria-based assessment and quantified higher education. The internal pressure and external demands embedded in a university culture driven by performance, rankings, funding, summative assessment, accreditation and governance run the risk of creating a higher education system characterized by fear of failure, avoidance of risk, reproduction of knowledge, and a focusing on goal-oriented behaviors, extrinsic motivation, and cost benefit analysis by teachers and students alike.

Here we offer a beginning for a pattern language for hybrid education that may function as a way of circumventing and pushing against the above mentioned current structures, demands, and experiences in higher education. Hybrid education proposes as a concept alternative values, activities, experiences, and formats. It is characterized by uncertainty, open-endedness, risk-taking, experimentation, empathy, disruption, dialogue, and critical creativity [Stommel 2012]. Hybrid education cuts across, transforms, or even transgress traditional boundaries and dichotomies in higher education and by doing so, asks of us to reflect on the reasons for, value in, and purpose of these dividing lines. Rorabaugh and Stommel have tried to encapsulate the concept of hybridity as follows:

[...] hybridity suggests hesitation at a threshold. Hybridity is not an attempt to neatly bridge the gap, but extends the moment of hesitation and thereby confuses easy categorization. And, as we allow two things to rub against each other, two things that might not otherwise touch, we invite them to interact, allowing synthesis (and even perforation) along their boundaries. As the digital and analog - the physical and virtual - commingle, we must let go of the containers for learning to which we've grown accustomed. We must open to random acts of pedagogy - to connections that are, like the web, associative and lively but sometimes violent and deformed. In this, hybridity is not always safe, moving incessantly (and dangerously) toward something new - something as yet undetermined. [Rorabaugh and Stommel 2012]

From the above description we can see how hybrid education carries within it the potential to resist and push against the managerialism and standardization of the commodified university. It also stresses the inherent risk in all education, that things are beyond our control and that it therefore needs careful reflection and reimagining along the way. In hybrid education people inside and outside the campus meet and intermingle, academic life becomes mongrel as the personal, professional, and academic merge. Teachers, students, and institutions cross-fertilize to construct new hybrid contexts and collectives across traditional boundaries. As such, the project evokes the concept of hybridity to explore and experiment with how education is constructed and performed in both university and extra-university spaces. Hybrid education, then, is about the transformative potential inherent in the different hybrid entanglements and intermingling of: physical-digital pedagogies and learning environments, academic and non-academic spaces, on-ground and online campus, disciplinarity and transdisciplinarity, formal-informal education, academia and citizenship, learning and teaching, walled and open universities, academic collectives and personal lives, on-campus and in-world teaching and learning, machine-human interaction and exploratory-experimenting education [Stommel 2012]. On the grounds of such different hybrid constellations, the possibility for new higher education futures emerges and even new conceptions of citizenship [Pedersen et al. 2018]. This paper presents design patterns for such new futures and conceptions.

\section{EDUCATIONAL PATTERNS AND PATTERN LANGUAGE: FRAMEWORK AND WORKSHOP}

Educational patterns provide teachers with examples of educational designs and a language for creating new educational designs. This idea of patterns and pattern language originates from the works of the architect Christopher W. Alexander and colleagues[Alexander et al. 1977]. Educational patterns are hypothesized solutions to recurring problems in an educational context e.g. the pattern PROBLEM ORIENTATION offers a solution to the difficulties of motivating the students when introducing a new topic. This pattern suggests to build on the students prior knowledge and to present a problem that the new topic solves [Fricke and Völter 2000]. Each pattern is part of a larger whole and works in relation to other patterns. Patterns are organized in a network structure and relate to other patterns. Educational patterns for hybridity 
share the fundamental view of patterns as expounded by Alexander et. al 1977, that patterns are not build in isolation but must also improve the world around them. Furthermore, each individual pattern is formatted in a manner that makes it possible for others to evaluate and possibly modify it without losing the essence of it. Educational patterns are examples of educational design that functions as representations of how to support learning in particular cases [Goodyear 2005]. They are procedural in nature and always open to further elaboration and improvement. Patterns can also be conceptual until they have been put to the test in real life setting.

Educational patterns cover areas such as learning with technology [Goodyear and Retalis 2010; Mor et al. 2014], MOOC-design [Warburton and Mor 2015], assessments [Bergin et al. 2015], flipped classrooms [Köppe et al. 2015], lecture design [Köppe 2013], seminars [Fricke and Völter 2000], or general pedagogical practices [Bergin et al. 2012].

\subsection{Pattern Mining Ground (process-part) ${ }^{1}$}

EduPLoP is part of the Pattern Languages of Programs (PLoP) conference series ${ }^{2}$ and supported by both the Hillside Group $^{3}$ and Hillside Europe ${ }^{4}$. It is designed as a pattern writing event where a small group of experts collaboratively works on identifying and describing patterns of a pre-defined domain in education. The first EduPLoP was held in 2015 in the Netherlands and the participants worked on patterns for Assessment-Driven Course Design [Bergin et al. 2015].

During the second EduPLoP16 at Sandbjerg Estate in Denmark on patterns for Hybrid Education the participants both worked on the concept of hybridity in education as well as working together in hybrid ways before, during and after the workshop through working digitally and materially, connecting remotely from around the globe from academic and non-academic spaces, working asynchronously and synchronously as well as individually and collectively. Through this framework a hybrid group of experts within design patterns, hybrid pedagogy, educational technologies and online education collaborated on identifying and describing patterns for Hybrid Education. The EduPLoP16 was supported by both Aarhus University (DK) and University of Surrey (UK).

As hybrid education on the one hand is firmly based within the field of critical pedagogy [Stommel 2012; Rorabaugh and Stommel 2012] and on the other hand is focused on designing for educational experiences and interactions the group took a human-centered [Giacomin 2014] and empathic [Gagnon and Côté 2014; Köppen and Meinel 2015; Battarbee et al. 2014] approach to (designing for) hybrid education. In doing so, EduPLoP16 was structured in a way that bears some resemblance with the concept of value-based vision-driven educational design thinking [Nørgård 2016; Aaen and Nørgård 2016; Mor et al. 2016] where design patterns are formed on the ground of specific virtues and values and driven by value-based visions. Accordingly, the EduPLoP16 workshop developed a pattern language for Hybrid Education through the following workshop structure:

(1) Value-based workshop to identify the core individual values of the hybrid participant group and establish a collective value framework for designing hybrid education. The value framework made the underlying values of the group's teaching and development practice explicit and enabled a collective alignment between the things we do (what and how) and the reasons for and purpose of doing so (why). The workshop was carried out to ensure that the group kept in touch with its educational values to realize the virtues, goals and purpose of hybrid education (see pictures from the value-based workshop and the developed values for Hybrid Education below)

(2) Vision-driven workshop to activate the collective values in individual visions for hybrid education and subsequently transform these into a collective position or manifest that guide the development of design patterns. In this way, the values and visions guided the decision-making and design-arguments of the following pattern workshops thus making the pattern design not only focused on the what and the how but also on the why of the teacher and student experiences and interactions fostered and promoted by the design patterns. Overall, the value and vision workshop enabled the development of an intentional pattern language for Hybrid Education that provided the group with a

\footnotetext{
${ }^{1}$ This process have be cited elsewhere see [Pedersen et al. 2018] and [Kohls et al. 2017]

$2_{\text {http: //hillside.net/conferences }}$

${ }^{3} \mathrm{http}: / /$ hillside.net

${ }^{4}$ http://europlop.net/content/organization
} 


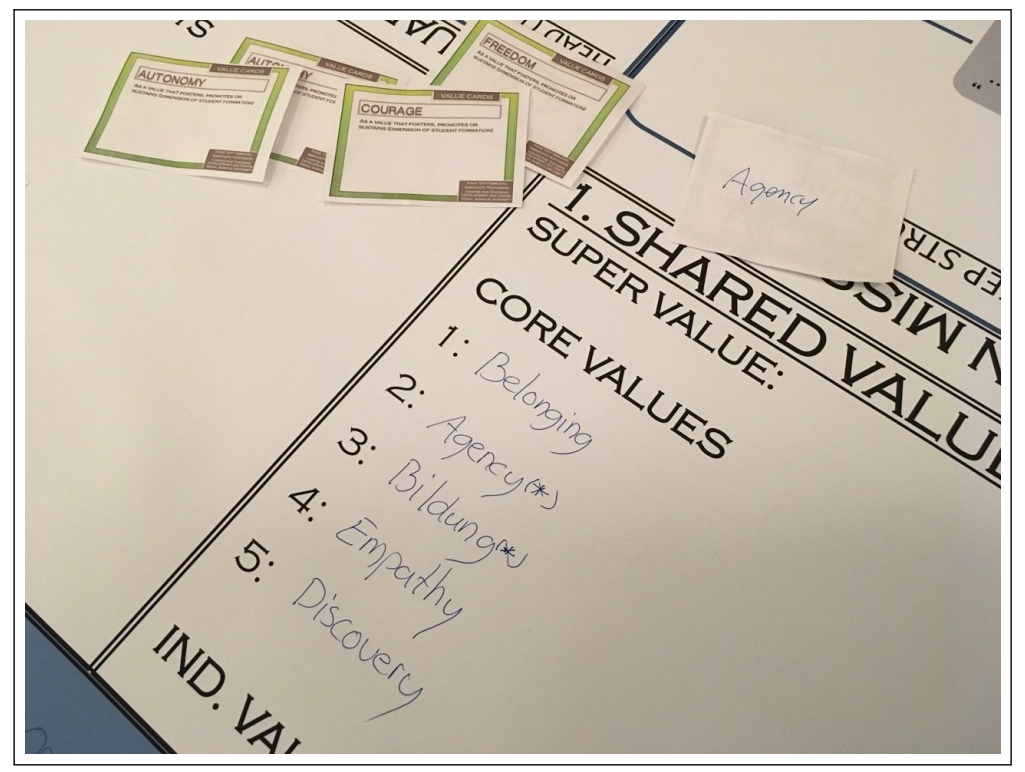

Fig. 1: identifying shared values in the vision-driven workshop

secure foundation and intentional drive in the next step of the process where design patterns were brainstormed and developed (see pictures from the vision-driven workshop and the developed visions for Hybrid Education below).

(3) Brainstorm session following the value and vision workshop to generate concrete examples of hybrid education from the group's own development and teaching practice. These examples spanned well above 100 post-it notes with specific titles of activities, practices and formats for Hybrid Education.

(4) Sorting workshop were the post-it notes were clustered and then sorted into higher-level categories. These categories combined a range of examples that were within the same affinity space. The clusters were given a common heading such as 'hybrid production' or 'inside out' to designate different areas of Hybrid Education. (see Figure 3)

(5) Pattern writing workshop following the brainstorm and clustering workshop to write op the different categories and examples as design patterns using a shared pattern template. The group split up in different online-onsite hybrid sub-groups containing experts from different fields and practices and shepherded by an expert within design pattern writing. The sub-groups distributed the different categories among them and moved them into pattern templates and categorization trees to develop a structured pattern language for Hybrid Education.

(6) Convergent-divergent hybrid pattern writing workshops were the online-onsite sub-groups met together to discuss, merge, exchange and elaborate on the different evolving design patterns within the groups. This was done in a co-constructive manner to check for redundancy between patterns and make sure that the different patterns aligned with the shared values and visions of the group. Special attention went into the formulation of a synopsis for each pattern candidate explicating both the what, how and why of the pattern through a process of repeating review and questioning from both face-to-face discussions and online collaboration in Google Docs.

(7) The result of the EduPLoP16 at Sandbjerg was approximately 85 unique pattern candidates distributed between 9 categories. The categories and patterns were arranged into a graphic mind map shoving related pattern candidates and every pattern had its own template under the different categories. By the end of the workshop some templates were still very rudimentary while some were more or less finished. All patterns were rated with *-symbols indicating the state they were currently in. Some patterns have already been described in more detail, e.g. in [Kohls et al. 2017]. 


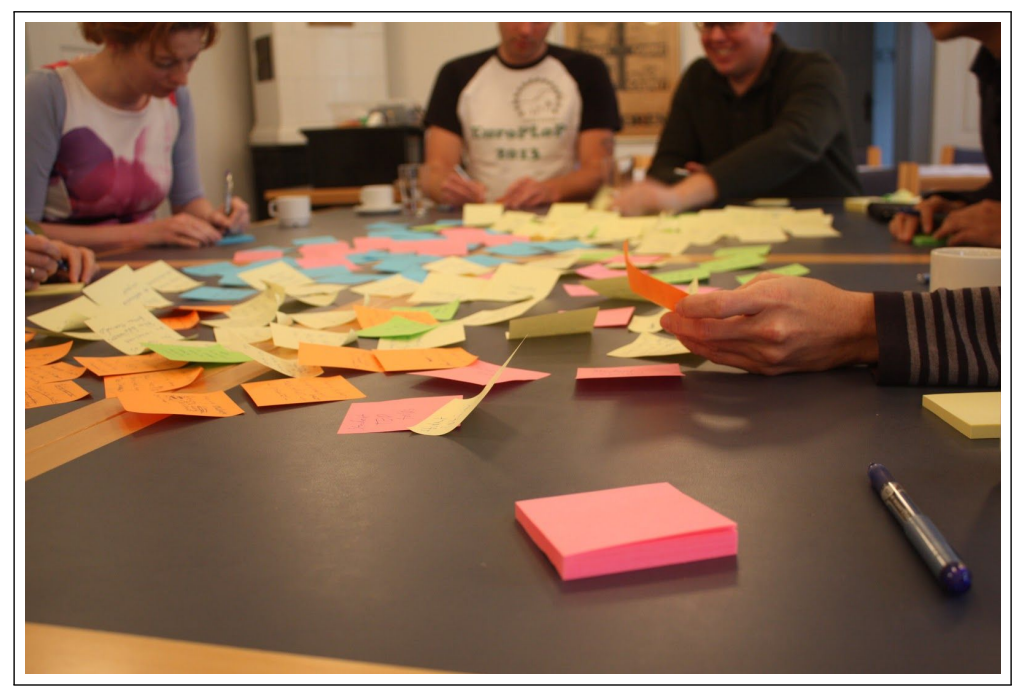

Fig. 2: brainstorming examples of hybrid education as base for pattern candidates

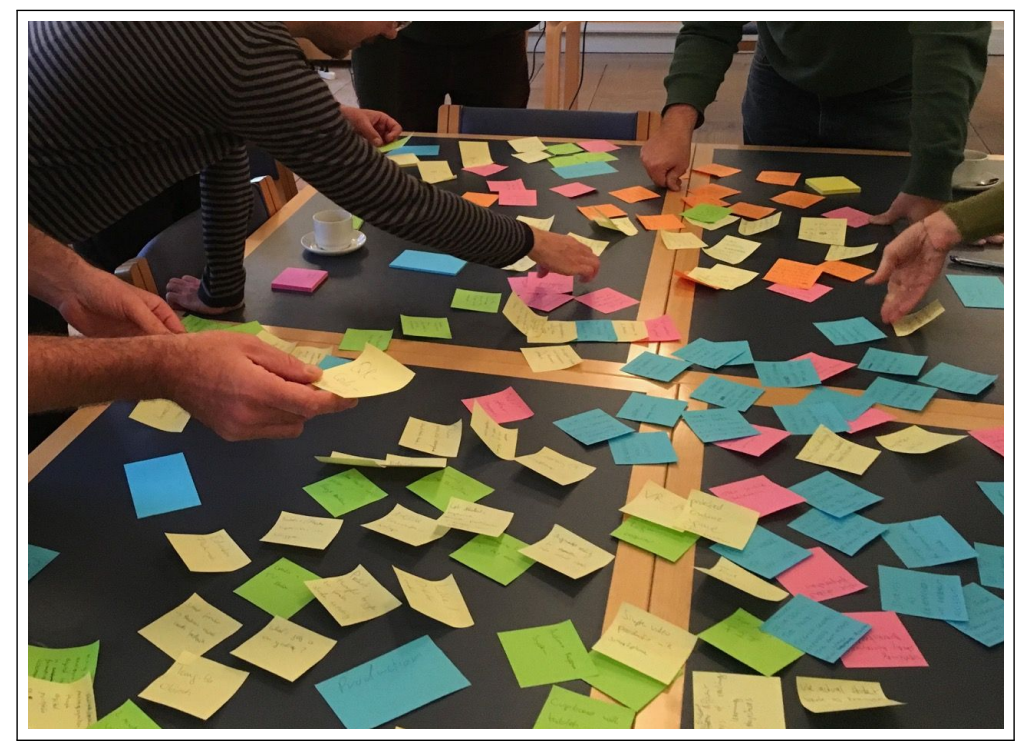

Fig. 3: clustering of post-its into higher order categories

\section{A PATTERN LANGUAGE OF HYBRID EDUCATION}

\subsection{Existing Patterns for Hybrid Education}

There is already a large body of knowledge described as educational patterns. Many of these patterns also include hybrid aspects, such as patterns for flipping the classroom [Köppe et al. 2015; Köppe et al. 2016] or patterns from the Pedagogical Patterns Project [Bergin et al. 2012]. However, these patterns did not focus on hybridity and therefore are likely missing some hybrid viewpoints in their descriptions. We therefore decided to initially not include them in the set 
presented in this work. In future work we will also relate the hybrid pedagogy patterns proposed in this work explicitly to the existing body of patterns, including the patterns that also address or realize hybrid aspects.

\subsection{Value-based Vision-driven Hybrid Educational Patterns}

As documented above, the development of a pattern language of Hybrid Education began with the value and vision workshop, here the group takes on a value-based vision-driven approach to design pattern development [Nørgård 2016; Aaen and Nørgård 2016; Mor et al. 2016]. The reason for positioning the question of why-ness of design — the values and visions - prior to the question of the how-ness and the what-ness, is because it is within the moral basis or virtues of educational design that the ability for a new emancipatory space in education arises [Nixon 2008]. In order to transform or innovate through educational design in ways that honour what is morally purposeful about education, and to avoid crude instrumentalism, we have to see it as 'all of a piece and understand how the various activities that comprise it hang together' [Nixon 2008]. In other words, when developing a pattern language for Hybrid Education we need to make sure that the why, how and what are intimately and inherently connected and integrated. Under this view, design patterns are always the putting into practice of what Nixon calls virtuous academic practice characterized by certain moral dispositions and a shared sense of moral purposefulness [Nixon 2008]. Here, the value-based vision-driven approach to developing a pattern language for Hybrid Education is taken to make explicit the moral bases of the values and visions that sustain such an effort. And also to practice those values and visions across a wide range of patterns. Or as Shulman puts it in Signature Pedagogies in the Professions: 'When the emotional content [the values] of learning is well sustained, we have a real possibility of pedagogies of formation [Bildung] - experiences of teaching and learning that can influence the values, dispositions, and characters of those who learn' [Shulman 2005].

Through the value-based, vision-driven approach each participant in the group started out by identifying the 5 core values driving their educational thinking and practice. These values were then shared and clustered into core values categories shared by the entire collective. Below the shared value foundation for Hybrid Education is listed ${ }^{5}$ :

\begin{tabular}{|l|l|}
\hline Core value category & Underlying values \\
\hline EMPATHY & Care, Respect, Commitment, Compassion, Sensitivity, Invitational. \\
\hline BELONGING \& BEING & Contribution, Sensitivity, Care, Generosity. \\
\hline PLAYFULNESS & Joy, Creativity, Curiosity, Exploration, Experimentation. \\
\hline AGENCY \& EMPOWERMENT & Autonomy, Resourcefulness, Self-determination, Freedom, Courage. \\
\hline BILDUNG & Thoughtfulness, Discipline, Professionalism. \\
\hline DISCOVERY & Experimentation, Curiosity, Exploration. \\
\hline
\end{tabular}

Values were put in place as a collective basis for their work on generating visions that should drive the development of Hybrid Education. Here, the values were integrated with the readings about hybrid pedagogy ahead of the workshop together with opening talks by online remote participants Maha Bali and Bonnie Stewart, one of the founders and editors of Hybrid Pedagogy - a digital journal of learning, teaching, and technology ${ }^{6}$. Fusing the notion of hybridity and hybrid pedagogy with the shared educational values created 1-2 individual vision statements that were then collected and put together to form a shared position statement about Hybrid Education. Below is the collective vision that drove the development of the pattern language for Hybrid Education ${ }^{7}$ :

\footnotetext{
${ }^{5}$ Note to table: also presented in [Pedersen et al. 2018, p. 232]

${ }^{6}$ http: //www. digitalpedagogylab.com/hybridped/

${ }^{7}$ Note to table: also presented in [Pedersen et al. 2018, p. 233]
} 


\begin{tabular}{|l|}
\hline Vision statements for a shared position on Hybrid Education \\
\hline Hybrid space strengthening belonging by broadening \& deepening perspectives \\
\hline Hybridity promotes critical interaction by confronting us with unexpected opportunities and challenges \\
\hline Hybridity fosters playfulness in order to develop openness through curiosity and experimentation \\
\hline $\begin{array}{l}\text { Hybridity promotes empowerment in order to establish autonomous learners through mutual respect and } \\
\text { empathy }\end{array}$ \\
\hline $\begin{array}{l}\text { Hybrid openness enables playfulness by empowering learners to help build the learning experience and } \\
\text { environment }\end{array}$ \\
\hline Hybridity invites experimentation through making the learning experience accessible and porous \\
\hline Hybrid pedagogy creates joy in order to increase the intrinsic motivation of students \\
\hline $\begin{array}{l}\text { Hybrid pedagogy supports empowerment in order to put control of the learning back in the hands of teachers } \\
\text { and students }\end{array}$ \\
\hline Hybridity engenders empathy and empowerment through playful engagement with self and other \\
\hline Hybrid openness promotes exploration by making uncertainty part of the course requirement \\
\hline $\begin{array}{l}\text { Hybrid learning supports exploration in order to develop innovative solutions through easy editing and saving } \\
\text { of steps }\end{array}$ \\
\hline Open hybridity empowers agency through possibilities of action and expression \\
\hline Hybrid space invites discovery through different means of inquiry \\
\hline $\begin{array}{l}\text { Hybrid learning enables belonging in order to respect and celebrate each individual view through unrestricted } \\
\text { contribution }\end{array}$ \\
\hline Hybrid learning fosters Bildung in order to enable people to express themselves through coping with challenges \\
\hline Hybrid space enable agency by tooling action in different ways \\
\hline Open hybridity enables discovery beyond institutions \\
\hline
\end{tabular}

On the backdrop of the development of a collective value-based vision-driven approach to a pattern language for Hybrid Education the group moved onto first brainstorming examples of hybridity in education and hybrid teaching and learning, then clustering and categorizing the examples into hybrid educational patterns.

\subsection{Hybrid Educational Pattern Candidates}

As described earlier, during the EduPLoP workshop there were approximately 85 pattern candidates identified. The level of description varied from just a rough idea to a fine-grained description of various aspects of the pattern candidate such as problem statement, forces, implementation details, consequences etc. At the end of the workshop all pattern candidates were at least described with a short synopsis which summarizes the core intention of the pattern. Three examples are given in the following list.

-REAl World Contribution - Assign students a task which requires them to create a modest contribution to a real-world context, make something which they can place in the real world, thus helping students to engage critically and proactively with social reality.

-BRING Your OWn Assignment - Students are less motivated to work on offered standard-assignments, so have them work on assignments they proposed themselves.

-FAMILY MATTERS - Make it possible to participate in education in a more flexible manner — both in terms of time and commitment. Also consciously legitimize and celebrate the different ways of participation in relation to other learners and the institutions.

The complete results with all pattern candidates and their synopses are presented in the Appendix. 


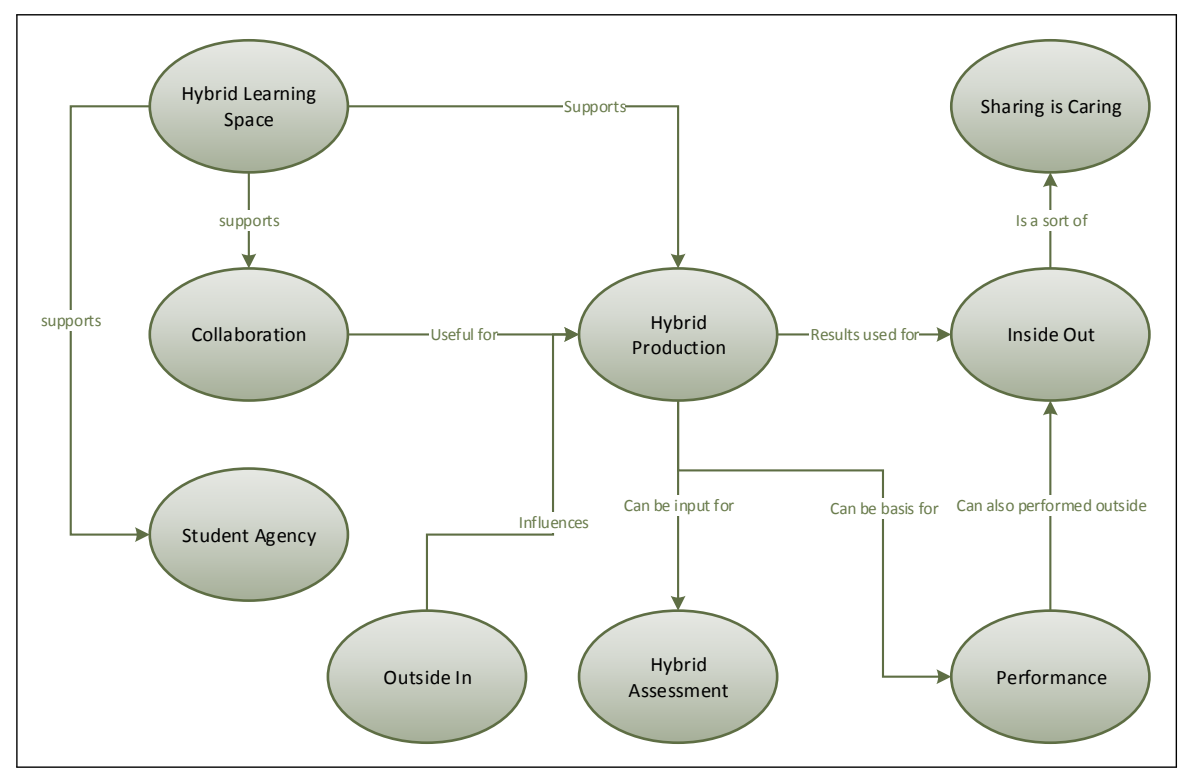

Fig. 4: pattern cluster map with connections

\subsection{Structuring Hybrid Educational Patterns}

In total we identified nine categories during the workshop: Hybrid Learning Space, Collaboration, Student Agency, Hybrid Production, Outside In, Hybrid Assessment, Performance, Inside Out, and Sharing is Caring. However, during the structuring process it became clear that many pattern candidates belong to multiple categories. In order to create an overview and possibly establish links between the categories, we decided to initially place all pattern candidates in the category deemed most fitting by the on-site participants. The complete mapping is presented in the Appendix of this paper.

In future work, we will extend this categorization and also will add other applicable categories. The diagram in Figure 4 illustrates the connections between the different clusters of the patterns.

Our intention is to evolve all pattern candidates to full patterns and to describe them completely in future work. The categories themselves also can be seen as high-level patterns, these patterns will be described in future work too.

\section{EXAMPLE SCENARIO}

HAN University of Applied Sciences in the Netherlands offers a part time study in computer science. The student population of this study differs tremendously from the full time students: they are working beside their study, they have families, and their choice for the study is often based on missing opportunities or knowledge of their current position. To reflect this specific situation in the study program, the current version will be reworked and include many hybrid aspects.

The following scenario shows how some of the proposed patterns can be applied for re-designing various aspects of the study program for part time students and how these patterns support the earlier defined values of hybrid education.

Part-time students who follow a course on object-oriented software development can suggest projects from their work as REAL WORLD CONTRIBUTION or look for COMMUNITY-DEFINED TASKS. For smaller tasks they could also BRING YouR OWN ASSIGNMENT which could be related to tasks from their work such as refactoring a piece of code or making an alternative design for a specific functionality of a software system. The students have to make use of ONLINE PROJECT MANAgement and StUdent PROJeCt Website ${ }^{8}$, which is especially helpful for part-time students as the face-to-face

${ }^{8}$ We use Confluence, a collaborative wiki-style environment: https: //www. atlassian.com/software/confluence 
time is quite limited and they also are not located at close-by places, but live throughout a larger region. This ONLINE PROJECT MANAGEMENT is also used for SitUATED FEEDBACK, given directly in the documentation as comments.

Software development requires tools which are not always easy to install, so there should be WORKING ENVIRONMENT GUARANTEED for all students and, in the case of problems, a TECHNOLOGY CONCIERGE.

Besides managing (and documenting) their project work online, students also have to post all other work on the online system. This realizes Creating StUdENT WORK TRANSPARENCY and invites other students to give feedback and learn from each other.

Part-time students of computer science have quite different backgrounds. They work with different programming languages, Integrated Development Environments, Software Development methodologies, programming paradigms etc. But also their specific home situations differ: they have children, are married, are singles etc. We did take these specific situations into account by offering MULTIPLE LEARNING PATHS and consciously support DIY EDUCATION which is happening independent of school.

It is also important to acknowledge that FAMILY MATTERS by offering more flexibility for participation at educational activities or for delivery deadlines (of course in agreement with their peers and the teacher). It also could be that a group of students has specific learning needs (such as how to apply Test-Driven Development) or wants to focus on a specific topic in more detail (such as performance issues in distributed environments). This could be realized through reserving some time of the course and to fill this with a CO-CONSTRUCTED CURRICULUM which can be decided on at the beginning of the course.

In order to prevent the teacher from a lot of additional work, the students can easily become STUDENTS AS CoCREATORS OF Course MATERIAL by asking them to collect and present material (e.g. through STUdENT-CREATED VIDEO TUTORIALS) and exercises (BRING YOUR OWN ASSIGNMENT).

The students are also asked to maintain a LEARNING JOURNAL. This way they are regularly reflecting on their own learning.

\section{SUMMARY/FUTURE WORK}

In this paper we presented the results of the 2nd EduPLoP workshop which form the initial framework of a pattern language for hybrid education. During that workshop, we identified about 85 pattern candidates which are presented completely in the appendix. In future work we intend to elaborate on all pattern candidates and refine them towards full patterns. The patterns themselves also will be applied and evaluated in new situations. Our intention is to help educators and educational designers with including hybrid aspects in their educational designs.

\section{ACKNOWLEDGEMENTS}

We thank our shepherd Peter Scupelli for his feedback on an earlier version of this work. We furthermore thank all participants of the EduPLoP workshop who all contributed to this work during the workshop. Finally we thank all participants of the writers' workshop at the VikingPLoP 2017 conference.

\section{REFERENCES}

Janus Holst Aaen and Rikke Toft Nørgård. 2016. Participatory academic communities: a transdisciplinary perspective on participation in education beyond the institution. Conjunctions. Transdisciplinary journal of cultural participation 2, 2 (2016), 67-98.

Christopher Alexander, Sara Ishikawa, and Murray Silverstein. 1977. A Pattern Language: Towns, Buildings, Construction. Oxford University Press.

Ronald Barnett. 2004. Learning for an unknown future. Higher Education Research \& Development 23, 3 (aug 2004), 247-260. DOI: http: //dx.doi.org/10.1080/0729436042000235382

Ronald Barnett. 2010. Being a university. Routledge, London.

Ronald Barnett. 2013. Imagining the University. INTERNATIONAL HIGHER EDUCATION (2013). DOI: http: //dx. doi.org/10.1080/14748460. 2013.802890

Katja Battarbee, Jane Fulton Suri, and Suzanne Gibbs Howard. 2014. Empathy on the edge: scaling and sustaining a human-centered approach in the evolving practice of design. Ideo (2014). 
Joe Bergin, Jutta Eckstein, Markus Völter, Marianna Sipos, Eugene Wallingford, Klaus Marquardt, Jane Chandler, Helen Sharp, and Mary Lynn Manns (Eds.). 2012. Pedagogical Patterns: Advice for Educators. Joseph Bergin Software Tools, New York, NY, USA. 230 pages.

Joe Bergin, Christian Kohls, Christian Köppe, Yishay Mor, Michel Portier, Till Schümmer, and Steven Warburton. 2015. Assessment-Driven Course Design - Foundational Patterns. In Proceedings of the 20th European Conference on Pattern Languages of Programs, EuroPLoP'15. ACM, Irsee, Germany.

Richard Budd. 2017. Undergraduate orientations towards higher education in Germany and England: problematizing the notion of 'student as customer'. Higher Education 73, 1 (jan 2017), 23-37. DOI : http://dx.doi .org/10.1007/s10734-015-9977-4

Ourania Filippakou and Gareth Lloyd Williams. 2015. Higher education as a public good: critical perspectives on theory, policy and practice. Peter Lang.

Astrid Fricke and Markus Völter. 2000. Seminars - A Pedagogical Pattern Language about teaching seminars effectively. In Proceedings of the 5th European Conference on Pattern Languages of Programs, EuroPLoP 2000. Irsee, Germany. http://www. voelter. de/data/pub/tp/tp. pdf

Caroline Gagnon and Valérie Côté. 2014. Learning from others: a five years experience on teaching empathic design. In Proceedings of Design Research Society Biennial International Conference DRS. 16-19.

Joseph Giacomin. 2014. What is human centred design? Design Journal (2014). DOI:http://dx.doi.org/10.2752/ 175630614 X14056185480186

Peter Goodyear. 2005. Educational design and networked learning: Patterns, pattern languages and design practice. Australasian Journal of Educational Technology 21, 1 (mar 2005). DOI:http://dx.doi.org/10.14742/ajet.1344

Peter Goodyear and Simeon Retalis (Eds.). 2010. Technology-Enhanced Learning: Design Patterns and Pattern Languages. Sense Publishers. 330 pages. http://www.amazon.com/Technology-Enhanced-Learning-Patterns-Pattern-Languages/dp/9460910602

Christian Kohls, Rikke Toft Nørgård, and Steven Warburton. 2017. Sharing is Caring. In Proceedings of the 22nd European Conference on Pattern Languages of Programs (EuroPLoP '17). ACM, New York, NY, USA, 34:1-34:6. DOI: http://dx. doi.org/10.1145/3147704.3147741

Christian Köppe. 2013. Towards a Pattern Language for Lecture Design: An inventory and categorization of existing lecture-relevant patterns. In Proceedings of the 18th European Conference on Pattern Languages of Programs, EuroPLoP'13. ACM, Irsee, Germany.

Christian Köppe, Ralph Niels, Rene Bakker, and Stijn Hoppenbrouwers. 2016. Flipped Classroom Patterns - Controlling the Pace. In Proceedings of the 10th Travelling Conference on Pattern Languages of Programs, VikingPLoP'16. ACM, Leerdam, Netherlands. DOI:http://dx.doi .org/10 . $1145 / 3022636.3022637$

Christian Köppe, Ralph Niels, Robert Holwerda, Lars Tijsma, Niek Van Diepen, Koen Van Turnhout, and Rene Bakker. 2015. Flipped Classroom Patterns - Designing Valuable In-Class Meetings. In Proceedings of the 20th European Conference on Pattern Languages of Programs, EuroPLoP'15. Irsee, Germany. DOI:http://dx.doi.org/10.1145/2855321.2855348

Eva Köppen and Christoph Meinel. 2015. Empathy via Design Thinking: Creation of Sense and Knowledge. In Design Thinking Research: Understanding Innovation. DOI:http://dx.doi.org/10.1007/978-3-319-19641-1

Ray Land. 2004. Educational development: Discourse, identity and practice. McGraw-Hill Education (UK).

Y Mor, H Mellar, S Warburton, and N Winters (Eds.). 2014. Practical design patterns for teaching and learning with technology. Sense Publishers, Rotterdam/Boston/Taipei. https://books.google.com/books?hl=en

Yishay Mor, Steven Warburton, Rikke Toft Nørgård, and Pierre Antoine Ullmo. 2016. MOOC design workshop: Educational innovation with empathy and intent. In Lecture Notes in Computer Science (including subseries Lecture Notes in Artificial Intelligence and Lecture Notes in Bioinformatics). DOI:http://dx.doi.org/10.1007/978-3-319-45153-4_42

Jon Nixon. 2008. Towards the virtuous university: The moral bases of academic practice. Routledge.

Rikke Toft Nørgård. 2016. Værdi-baseret visions-drevet didaktisk design tænkning: Innovation i undervisningen gennem intentionel brug af teknologier. In DUN-Conference. Nyborg.

Alex Young Pedersen, Rikke Toft Nørgård, and Christian Köppe. 2018. Patterns of Inclusion: Fostering Digital Citizenship through Hybrid Education. Journal of Educational Technology \& Society 21, 1 (2018), 225-236. http: //www. ifets. info/ journals/21

Pete Rorabaugh and Jesse Stommel. 2012. Hybridity, pt. 3: What Does Hybrid Pedagogy Do? - Hybrid Pedagogy. (2012). http://www. digitalpedagogylab.com/hybridped/hybridity-pt-3-what-does-hybrid-pedagogy-do/

Lee S. Shulman. 2005. Signature pedagogies in the professions. Daedalus (2005). DOI: http://dx.doi.org/10.1162/0011526054622015

Wesley Shumar. 1997. College for sale: A critique of the commodification of higher education. Psychology Press.

J. Stommel. 2012. Hybridity part 2, what is hybrid pedagogy. (2012). http://www.digitalpedagogylab.com/hybridped/ hybridity-pt-2-what-is-hybrid-pedagogy/

Steven Warburton and Yishay Mor. 2015. A set of patterns for the structured design of MOOCs. Open Learning: The Journal of Open, Distance and e-Learning 30, 3 (sep 2015), 206-220. DOI : http://dx.doi.org/10.1080/02680513.2015.1100070 


\section{Appendix}

The following tables provide a complete overview of all pattern candidates which were identified during the EduPLoP 2016 workshop. They are grouped by using the earlier described clusters and for each pattern candidate a potential name and a synopsis are given.

\section{Hybrid Production}

The production of artefacts using other than the standard elements (materials, procedures, requirements, etc.) than usual or changing some requirements such as place, time, or ways of collaboration.

\begin{tabular}{|l|l|}
\hline Pattern Candidate & Synopsis \\
\hline REAL WORLD CONTRIBUTION & $\begin{array}{l}\text { Assign students a task which requires them to create a modest contribution to a real-world context, } \\
\text { make something which they can place in the real world, thus helping students to engage critically } \\
\text { and proactively with social reality. }\end{array}$ \\
\hline GUERILLA ART & $\begin{array}{l}\text { A special case of REAL WORLD CONTRIBUTION, in which students create a small provocative } \\
\text { intervention in a public space. }\end{array}$ \\
\hline PARTNERSHIP PROJECTS & $\begin{array}{l}\text { A special case of REAL WORLD CONTRIBUTION, in which students create work in partnership with } \\
\text { external stakeholders on a real-life, actual problem or challenge the stakeholder is facing. }\end{array}$ \\
\hline DAILY SHOWCASE ARTEFACT & $\begin{array}{l}\text { Give your students a short creative task every day, which results in an artefact they can display and } \\
\text { share. }\end{array}$ \\
\hline RAPID PROTOTYPING & $\begin{array}{l}\text { Set a production task for your students, and give them a short time to complete it (enough to get } \\
\text { something done, but not enough to perfect it or obsess over it). Take advantage of technology that } \\
\text { supports rapid production, and of free open resources, even if this comes at the expense of the } \\
\text { quality of the product. The task should require students to mix contexts or cross boundaries, in a } \\
\text { way that is not familiar to them. }\end{array}$ \\
\hline RE-MEDIATION & $\begin{array}{l}\text { Re-mediate the task and ask the learners to do something somewhat familiar, but in a different way } \\
\text { or through a displaced or refocused lens, in order to promote more reflection on what they're doing } \\
\text { and critical inter/action through playful confrontation with unexpected opportunities and challenges. }\end{array}$ \\
\hline HYBRID CURATING & $\begin{array}{l}\text { Instruct learners to create online visual scrapboards which include found digital artefacts and } \\
\text { captured / created visuals of real-world objects. These boards should be organised to reflect a } \\
\text { conceptual understanding of a defined theme. }\end{array}$ \\
\hline HYBRID CO-CREATING & \begin{tabular}{l} 
Making tangible objects together through online dialogues and meet-ups. \\
\hline
\end{tabular} \\
\hline
\end{tabular}

\section{Hybrid Learning Space}

The configuration of hybrid spaces to enable students to work, interact, collaborate and to learn in a manner suitable to their needs.

\begin{tabular}{|l|l|}
\hline Pattern Candidate & Synopsis \\
\hline INTERACTIVE TANGIBLE OBJECTS & $\begin{array}{l}\text { Make tangible objects connect to the virtual world. A tangible object can trigger digital actions, e.g. } \\
\text { opening a web site or digital worksheet. }\end{array}$ \\
\hline CONNECTED INTERACTIVE WALLS & $\begin{array}{l}\text { Provide opportunities to interact with large scale interactive walls in the physical space as well as in } \\
\text { the digital space. }\end{array}$ \\
\hline $\begin{array}{l}\text { WORKING ENVIRONMENT GUARAN- } \\
\text { TEED }\end{array}$ & $\begin{array}{l}\text { Ensure that all students have a working environment (the required tools for working on a } \\
\text { task/assignment/project) at the very beginning so that they don't unnecessarily waste time with fixing } \\
\text { the environment until it works. }\end{array}$ \\
\hline TECHNOLOGY CONCIERGE & $\begin{array}{l}\text { When there is dependence on technology for the continuity of an event/project/task etc., have } \\
\text { a concierge who is sufficiently available and has the abilities (and authority) to fix the occurring } \\
\text { problems with the technology as fast as possible. }\end{array}$ \\
\hline
\end{tabular}


Table II - continued from previous page

\begin{tabular}{|l|l|}
\hline Pattern Candidate & Synopsis \\
\hline BRING YOUR OWN DEVICE & $\begin{array}{l}\text { Students use their own personal devices to contribute to in/out classroom activities. They have the } \\
\text { responsibility to install the required apps etc. }\end{array}$ \\
\hline TABLET/DEVICE CABINET & $\begin{array}{l}\text { Have a cabinet with standardized tablets/devices: same configuration, same apps etc. The setup of } \\
\text { the tablets/devices can be exactly as needed for the learning scenario. It is ensured that all students } \\
\text { have equal equipment, no one is left behind. }\end{array}$ \\
\hline ONLINE PROJECT MANAGEMENT & Have the students manage their project using an online tool. \\
\hline STUDENT COURSE AGGREGATOR & $\begin{array}{l}\text { If students are using their own (personal) tools for documenting their work, a course aggregator can } \\
\text { gather student work and present it in one place. }\end{array}$ \\
\hline
\end{tabular}

\section{Hybrid Assessment}

To allow for multiple instances and forms of formative assessment involving both peer-to-peer, supervision and feedback. Focus on informal and low-stake assessment with the goal to create an environment of learning.

\begin{tabular}{|l|l|}
\hline Pattern Candidate & Synopsis \\
\hline ONLINE SUPERVISION & $\begin{array}{l}\text { Use video and audio-graphical conferencing tools to conduct supervision sessions so that you also } \\
\text { can help students who are not able to meet face-to-face. }\end{array}$ \\
\hline OPEN ONLINE SUPERVISION & $\begin{array}{l}\text { Record your ONLINE SUPERVISION and share it online, either with the course cohort (in the GATED } \\
\text { COMMUNITY) or openly. }\end{array}$ \\
\hline SNAPCHAT ASSESSMENT & $\begin{array}{l}\text { Snapchat is ephemeral and for sharing imperfection, so try to establish trust by allowing learners to } \\
\text { be messy and imperfect together with the teacher as opportunities for learning and development. }\end{array}$ \\
\hline SITUATED FEEDBACK & $\begin{array}{l}\text { In order to help students master a certain competence or skill, you design a procedure involving } \\
\text { MULTIPLE DRAFTS that receives feedback from teachers situated directly within the given text or } \\
\text { product that the student develops. }\end{array}$ \\
\hline
\end{tabular}

\section{Performance}

Introduce an element of public performance whereby students are sharing and presenting their work to a wider and more heterogeneous audience. Performing or publicly presenting will enhance student learning.

Most of these patterns are specialisations of RE-MEDIATION (see Section Hybrid Production).

\begin{tabular}{|l|l|}
\hline Pattern Candidate & Synopsis \\
\hline STUDENT TED TALKS & Students share their work in TED talk style presentations. \\
\hline STUDENT BOOKLETS & $\begin{array}{l}\text { Students turn their exam papers / final assignment into a publicly accessible booklet / a booklet that } \\
\text { can be read by the public. }\end{array}$ \\
\hline RESEARCH MUSIC VIDEOS & $\begin{array}{l}\text { Students or teachers presents theory, concepts, frameworks, research or other academic work in the } \\
\text { form of music videos. }\end{array}$ \\
\hline ROBOTS TELLING STORIES & $\begin{array}{l}\text { Using tools from one field (like robotics or computer programming or digital design) to engage with } \\
\text { the subject matter of another field (like philosophy, literature or history). }\end{array}$ \\
\hline
\end{tabular}




\section{Student Agency}

Student are not blank slates. Therefore try to utilise the knowledge they bring to school. Also students are not alike. They will have different interests and knowledge which can be very productive in an educational context.

\begin{tabular}{|c|c|}
\hline Pattern Candidate & Synopsis \\
\hline $\begin{array}{l}\text { CREATING STUDENT WORK TRANS- } \\
\text { PARENCY }\end{array}$ & $\begin{array}{l}\text { Have students do small assignments (that take on the form of text, pictures and/or video) and post } \\
\text { them in blog posts or a wiki several times during the course. The posts or the wiki are open to } \\
\text { comments and discussion from both other students and the teachers. }\end{array}$ \\
\hline $\begin{array}{l}\text { STUDENT OWNED PROJECT DO- } \\
\text { MAINS }\end{array}$ & $\begin{array}{l}\text { Have students get their own domain (and maybe webhosting) and take ownership of their online } \\
\text { presence. A student owned project domain can support students' ownership of their work, it can } \\
\text { support project work (as a log of activities and preliminary work), and it can be used as a showcase } \\
\text { for student work. }\end{array}$ \\
\hline STUDENTS AS TEACHERS & $\begin{array}{l}\text { Have students teach (selected) parts of a course to other students in their own ways in order to break } \\
\text { the strict teacher-student separation. This will create a more in-depth understanding of the topic, } \\
\text { foster engagement with their own learning and that of their peers, and also can simply be fun to do. }\end{array}$ \\
\hline $\begin{array}{l}\text { STUDENT-CREATED VIDEO TUTORI- } \\
\text { ALS }\end{array}$ & $\begin{array}{l}\text { Have students create (and blog) tutorials for the other students. (specialization of STUDENTS AS } \\
\text { TEACHERS) }\end{array}$ \\
\hline UNDERCOVER ACTORS & $\begin{array}{l}\text { On the first day at University or High-School place undercover actors (older learners) in the large } \\
\text { group of new student. These play the role of extreme personalities that draw attention from group } \\
\text { and can become the 'talk of the town'. }\end{array}$ \\
\hline DIY EDUCATION & $\begin{array}{l}\text { Acknowledge and support that learners design their own education which often takes place without } \\
\text { the teachers knowing or perhaps even outside formal education. }\end{array}$ \\
\hline BRING YOUR OWN ASSIGNMENT & $\begin{array}{l}\text { Students are less motivated to work on offered standard-assignments, so have them work on } \\
\text { assignments they proposed themselves. }\end{array}$ \\
\hline REBEL STUDENTS & When students rebel, don't resist. Open up the space for them to reconstruct the learning experience. \\
\hline NO TEACHER FB GROUP & $\begin{array}{l}\text { Acknowledge and encourage learners to create and manage social learning spaces where you as } \\
\text { the educator are not present. }\end{array}$ \\
\hline FAMILY MATTERS & $\begin{array}{l}\text { Make it possible to participate in education in a more flexible manner - both in terms of time and } \\
\text { commitment. Also consciously legitimize and celebrate the different ways of participation in relation } \\
\text { to other learners and the institutions. }\end{array}$ \\
\hline Co-CONStRucted CuRRICULUM & $\begin{array}{l}\text { Use a collaborative editing medium to co-construct with the learners a curriculum for your course, } \\
\text { this will create an increased student's ownership of the course content and in consequence a higher } \\
\text { motivation for learning. }\end{array}$ \\
\hline $\begin{array}{l}\text { STUDENTS AS CO-CREATORS OF } \\
\text { COURSE MATERIAL }\end{array}$ & $\begin{array}{l}\text { Students are asked to search for and contribute with course material that adds to the existing syllabus } \\
\text { of a course. Students develop a shared collection of annotated/commented course material. }\end{array}$ \\
\hline MULTIPLE LEARNING PATHS & $\begin{array}{l}\text { Design your course to allow alternative paths, combining hybrid interactions in different ways, for } \\
\text { reaching the learning objectives to account for diverse learner circumstances and preferences. }\end{array}$ \\
\hline
\end{tabular}

Outside In

Bringing the public into learning.

\begin{tabular}{|l|l|}
\hline Pattern Candidate & Synopsis \\
\hline INTEGRATING PRACTITIONERS & $\begin{array}{l}\text { Connecting a course to real-world practices by bringing into the classroom people, activities, problems } \\
\text { and tools. They can take on the form of cases. }\end{array}$ \\
\hline $\begin{array}{l}\text { VISUAL DOCUMENTATION OF OUT- } \\
\text { SIDE PRACTICES }\end{array}$ & Bringing real life stories and visual representations into the classroom by students who are off-site. \\
\hline COMMUNITY-DEFINED TASKS & $\begin{array}{l}\text { Ask a community to define meaningful tasks for the students based on real community needs, to } \\
\text { develop students' responsibility, which opens opportunities to engage students with the community. }\end{array}$ \\
\hline \multicolumn{2}{|c}{ Continued on next page } \\
\hline
\end{tabular}


Table VI - continued from previous page

\begin{tabular}{|l|l|}
\hline Pattern Candidate & Synopsis \\
\hline SOURCING EXPERTISE & Bringing expertise into the classroom through online resources from experts. \\
\hline ENGAGING WITH EXPERTS & $\begin{array}{l}\text { Bringing in external experts to engage in dialogue with students and their work. The experts can } \\
\text { bring in additional expertise through presentations, and they can also provide new perspectives by } \\
\text { giving feedback and discussing student work. }\end{array}$ \\
\hline DIVERSE PEER INTERACTION & $\begin{array}{l}\text { Set students tasks that require them to interact with peers of diverse backgrounds, to promote } \\
\text { empathy and an understanding of multiple perspectives. }\end{array}$ \\
\hline JOINT FACT FINDING & $\begin{array}{l}\text { A process for finding with others a shared point of departure for further discussion on issues that } \\
\text { may be controversial. }\end{array}$ \\
\hline EXPERIMENTS FOR REAL & $\begin{array}{l}\text { Implement a real life experiment that illustrates the theoretical points in a meaningful way to scaffold } \\
\text { learners comprehension. }\end{array}$ \\
\hline STUDENT RUN WEBINAR & $\begin{array}{l}\text { Students present their work and facilitate group discussions with (external) participants in a webinar. } \\
\text { Engages students with externals in a live discussion around their product (specific form of ENGAGING } \\
\text { WITH EXPERTS). Teachers can disappear, students are the experts. }\end{array}$ \\
\hline
\end{tabular}

\section{Inside Out}

Taking learning to the public space. These patterns are further split into three areas.

In public (presence)

\begin{tabular}{|l|l|}
\hline Pattern Candidate & Synopsis \\
\hline NOMADIC STUDENT & $\begin{array}{l}\text { Students taking classes wherever they are in the world. Like Coffee Shops or Supermarkets or in the } \\
\text { forest. Or in the bus. In this way, students are being re-localised rather than becoming in-tangible } \\
\text { virtual students. }\end{array}$ \\
\hline FIND STUDENTS NEARBY & $\begin{array}{l}\text { The NOMADIC STUDENT learns at many different places. S/he still wants to learn with other peers } \\
\text { and needs to find them. Hence, it is interesting to know and team up with students who are in the } \\
\text { same area. For example, students in the same neighbourhood can meet in the café around the } \\
\text { corner. }\end{array}$ \\
\hline STREET TASKS & $\begin{array}{l}\text { Bring the students out to the streets to have real world experience. Assign activities that bring } \\
\text { individuals or groups to engage in out of classroom experiences. Students should learn experimenting } \\
\text { with/in the world. This can help to finding their self through interaction with people. }\end{array}$ \\
\hline RUNAWAY CLASSROOM & $\begin{array}{l}\text { Students (with or without teacher) self-organize to meet at a specific location to have a shared } \\
\text { transient learning experience that have the transformatory potential either for the flashmob or the } \\
\text { audience. }\end{array}$ \\
\hline $\begin{array}{l}\text { A classroom can be anywhere, and NomADIC STUDENTs can form a classroom everywhere. This is } \\
\text { sometimes supported or organized by a teacher that takes the entire classroom 'in the backpack' } \\
\text { and into the world. In this way the runaway classroom has left the campus to go somewhere } \\
\text { else. Consequently, the classroom can be everywhere creating a hybrid in the form of a digital } \\
\text { un-classroom or a physical re-localised classroom camping somewhere else whether it is the city, } \\
\text { the sea, the sky or underground. }\end{array}$ \\
\hline TEACHER HUB & $\begin{array}{l}\text { While learning can take place everywhere, very often the teacher still is a natural center for commu- } \\
\text { nication, collaboration and inspiration. }\end{array}$ \\
\hline
\end{tabular}

For the public (display) 


\begin{tabular}{|l|l|}
\hline Pattern Candidate & Synopsis \\
\hline STUDENT PROJECT WEBSITE & $\begin{array}{l}\text { Encourage (or require) your students to setup a website that informs others about their project. } \\
\text { The website could state the goals, show team members, inform about the work in progress and } \\
\text { milestones (OPEN DEVELOPMENT). The final outcomes should be presented there as well. }\end{array}$ \\
\hline $\begin{array}{l}\text { COLLABORATIVE OPEN ONLINE } \\
\text { PROJECTS }\end{array}$ & $\begin{array}{l}\text { Create online projects in which your students work together with people outside the course to engage } \\
\text { them with societal issues and make meaningful contact/use of expertise in a range of fields. }\end{array}$ \\
\hline MASSIVE OPEN ONLINE PROJECTS & $\begin{array}{l}\text { This is a refinement of COLLABORATIVE OPEN ONLINE PROJECTS. Instead of running MOOCs with } \\
\text { instructions and assignments, you create a learning experience by organizing a large scale project. }\end{array}$ \\
\hline
\end{tabular}

\section{With the public (interaction)}

\begin{tabular}{|l|l|}
\hline Pattern Candidate & Synopsis \\
\hline OPEN HYBRID CLASSROOM & $\begin{array}{l}\text { Open up the classroom in a way that invites the world inside and reconnects the classroom with the } \\
\text { world. Invite people to join the classroom and establish clear rules of engagement for both visitors } \\
\text { and your students. }\end{array}$ \\
\hline $\begin{array}{l}\text { BUILDING PROFESSIONAL NET- } \\
\text { WORKS }\end{array}$ & $\begin{array}{l}\text { Developing a personal professional network that moves beyond the student's class and institution can } \\
\text { both strengthen the student's study activities by providing additional input and support the student } \\
\text { after qualifying by providing them with a network that can help them in their professional work. }\end{array}$ \\
\hline
\end{tabular}

\section{Sharing is Caring}

Create opportunities to share learning resources, knowledge and new ideas to promote a culture of sharing.

\begin{tabular}{|l|l|}
\hline Pattern Candidate & Synopsis \\
\hline SHARING PROCESS & Make the steps of a process public. \\
\hline LEARNING JOURNAL & $\begin{array}{l}\text { Promote reflection and a sense of learning community by asking learners to post regular short texts, } \\
\text { where they share and reflect on their personal learning experience. }\end{array}$ \\
\hline $\begin{array}{l}\text { OPEN DEVELOPMENT / OPEN RE- } \\
\text { SEARCH }\end{array}$ & $\begin{array}{l}\text { Share the work-in-progress in order to let others anticipate and comment on your ideas. Ideas in an } \\
\text { early stage can already inspire others. Don't be afraid of other people stealing your ideas. It is more } \\
\text { likely that they will inspire you as much as you inspire them. }\end{array}$ \\
\hline SHOW THE PROCESS & $\begin{array}{l}\text { Show (steps of) the process when the product is done in reflective e-portfolios (see Bauer \& } \\
\text { Baumgartner 2012), or on a STUDENT PrOJECT WEBSITE. }\end{array}$ \\
\hline $\begin{array}{l}\text { SHARING STORIES OF LEARNING } \\
\text { JOURNEYS }\end{array}$ & $\begin{array}{l}\text { Give students an opportunity to share the stories of their learning journey, so that they can learn } \\
\text { from each others' experience and reflect on their own. }\end{array}$ \\
\hline RAPID SHARE & Making sharing quick by using new technological potentials like twitter hashtags, links, padlets. \\
\hline OPEN CC SHARING & $\begin{array}{l}\text { Actively make your work and assignments accessible by sharing via Creative Commons licensing. } \\
\text { Relates to RAPID SHARE and RESPONSIBLE MASHUPS. }\end{array}$ \\
\hline RAPID IMAGE SHARING & Minimize the number of steps to bring an existing or new pictures to a shared space. \\
\hline NO LOGIN & $\begin{array}{l}\text { Many sessions do not really need personal identification. The service can be used right away. People } \\
\text { can verify that they belong to a group by sharing a random ID that is generated ad-hoc for each } \\
\text { session. }\end{array}$ \\
\hline $\begin{array}{l}\text { SHARING PRODUCTS AS OPEN } \\
\text { (RE)SOURCES }\end{array}$ & $\begin{array}{l}\text { Make the outcomes of project accessible to the public. This makes the making process more } \\
\text { meaningful. Others can learn and reuse the work others have created. }\end{array}$ \\
\hline TEACHER BLOGGING & $\begin{array}{l}\text { Teachers post messages that are relevant to their students. These messages can be information } \\
\text { about courses, content, or the research a teacher is doing. }\end{array}$ \\
\hline
\end{tabular}




\section{Table $\mathrm{X}$ - continued from previous page}

\begin{tabular}{|c|c|}
\hline Pattern Candidate & Synopsis \\
\hline PUBLIC EXAMS & $\begin{array}{l}\text { Organize exams in public spaces rather than the private wall of a university. When put in the public, } \\
\text { the meaning and importance of exams is lifted to a higher and more meaningful level. Students may } \\
\text { invest more time and take exams more serious. They also get into contact with the real world, and } \\
\text { there are opportunities for networking. }\end{array}$ \\
\hline StUdENT PROJECT WEBSITE & Encourage (or require) your students to set up a website that informs others about their project. \\
\hline STUDENT CONFERENCE & $\begin{array}{l}\text { Students are setting up a conference or event for the benefit of others. They can display their own } \\
\text { work or act as trainers to others. }\end{array}$ \\
\hline RESPONSIBLE MASHUPS & $\begin{array}{l}\text { Allow mashups, even 'copy and paste' documents but establish clear rules what is a fair use of } \\
\text { external resources. }\end{array}$ \\
\hline HYBRID GROUP SHARE & $\begin{array}{l}\text { NOMADIC STUDENTs work from different spaces yet they want to share their results and contribu- } \\
\text { tions in a shared space. This can be done with a shared group folder, or - in case of photos taking } \\
\text { from the real world artefacts - using RAPID IMAGE SHARE. }\end{array}$ \\
\hline COURSE INTERSECTIONS & $\begin{array}{l}\text { Create intersections between different courses or different institutions that intersects at specific } \\
\text { points to share material, discuss, present, teach each other etc. in order to prompt students to reflect } \\
\text { on their discourse and practice and sense the value of their work. }\end{array}$ \\
\hline COLLECTIVE OWNERSHIP & $\begin{array}{l}\text { Establish a collective spirit where the products created are not owned by individual participants but } \\
\text { the collective of the group. Instead of 'signing' each individual contribution, use Design Team Names } \\
\text { for products and processes. }\end{array}$ \\
\hline BIDIRECTIONAL HOME VISITS & $\begin{array}{l}\text { Rather than meeting online in a virtual space people are meeting at 'home' in the private homes of } \\
\text { the different speakers. }\end{array}$ \\
\hline INTER-UNIVERSITY TEACHING & $\begin{array}{l}\text { In inter-university teaching and learning teachers teach on each others courses across different } \\
\text { universities by virtually connecting into each other classrooms/courses to teach, discuss or have } \\
\text { dialogues with each other's students. Also they might encourage the students of their courses to } \\
\text { get into dialogue with each other either during the inter-university meet-up or afterwards using e.g. } \\
\text { Twitter, Facebook or Google Hangout to connect, discuss and collaborate across universities. }\end{array}$ \\
\hline $\begin{array}{l}\text { CONNECT STUDENTS WITH YOUR } \\
\text { NETWORK }\end{array}$ & $\begin{array}{l}\text { Allow students to connect with your (online) network for discussion and possible guidance. This is } \\
\text { related to BUILDING PROFESSIONAL NETWORKS. }\end{array}$ \\
\hline
\end{tabular}

\section{Collaboration}

Move collaboration from the context of the classroom to a wider public to utilize the resources of other people, groups and forums.

\begin{tabular}{|l|l|}
\hline Pattern Candidate & Synopsis \\
\hline DAILY BULLETIN & $\begin{array}{l}\text { Send out a daily account of the events in a course, so that remote learners can maintain a sense of } \\
\text { direction and participation. }\end{array}$ \\
\hline $\begin{array}{l}\text { STUDENT SHARED RESOURCE } \\
\text { SPACE }\end{array}$ & $\begin{array}{l}\text { In order to promote ownership of resources and have students make experience with looking for } \\
\text { resources, provide a space where they can share resources and have experience of doing non-textual } \\
\text { literature searches that are meaningful. }\end{array}$ \\
\hline BREAK OUT, BRING IN & $\begin{array}{l}\text { Enable large groups to split up to work on sub-problems or themes and to easily share their results } \\
\text { and work progress with the initial group members. }\end{array}$ \\
\hline HYBRID CLASSROOM DISCUSSION & $\begin{array}{l}\text { Combination of different technologies can afford the moving of the learners to the center-stage and } \\
\text { de-center the teacher. }\end{array}$ \\
\hline RAPID DISCUSSION & Open an ad-hoc discussion using a collaborative medium to break down hierarchies. \\
\hline RAPID OPEN DISCUSSION & $\begin{array}{l}\text { Open an ad-hoc discussion in class using an open medium (e.g. using a twitter \#tag), to break down } \\
\text { hierarchies and benefit from unexpected interactions. }\end{array}$ \\
\hline RAPID CLOSED DISCUSSION & $\begin{array}{l}\text { Open an ad-hoc discussion in class using a closed medium to break down hierarchies while } \\
\text { maintaining the protection of a GATED ComMUNITY. }\end{array}$ \\
\hline
\end{tabular}

Continued on next page 
Table XI - continued from previous page

\begin{tabular}{|l|l|}
\hline Pattern Candidate & Synopsis \\
\hline COLLECTIVE ANNOTATION & $\begin{array}{l}\text { Students in small groups or in a class annotate and write comments on the same texts, videos or } \\
\text { pictures. }\end{array}$ \\
\hline
\end{tabular}

VikingPLoP'17, March 30 - April 2, Grube, Schleswig-Holstein, Germany. Copyright is held by the owner/author(s). Publication rights licensed to ACM. ACM ISBN 978-1-4503-6342-6/17/03 \$15.00

https://doi.org/10.1145/3158491.3158504

Towards a Pattern Language for Hybrid Education — Page XVII 